\title{
Old and New Minorities: Diversity Governance and Social Cohesion from the Perspective of Minority Rights
}

\author{
Roberta MEDDA-WINDISCHER \\ European Academy of Bolzano/Bozen \\ Department 'Institute for Minority Rights' \\ Roberta.Medda@eurac.edu
}

\begin{abstract}
Minority rights instruments have been traditionally applied to old minority groups. This paper examines to what extent these same instruments are conceptually meaningful to the integration of new minorities stemming from migration. The conviction that minority groups, irrespective of their being old or new minorities, have some basic common claims that can be subsumed under a common definition does not mean that all minority groups have all the same rights and legitimate claims: some have only minimum rights, while others have or should be granted more substantial rights; some can legitimately put forward certain claims not enforceable rights - that need to be negotiated with the majority, while others should not. In order to devise a common but differentiated set of rights and obligations for old and new minority groups, it is essential to analyse the differences and similarities of both categories of minorities, their claims, needs, and priorities; in this way, it will be possible to delineate a catalogue of rights that can be demanded by and granted to different minority groups. Studying the interaction between traditional minorities and migrants or old and new minority groups is a rather new task because so far these topics have been studied in isolation from each other. It is also an important task for future research in Europe since many states have established systems for the rights of old minorities but have not as yet developed sound policies for the integration of new minority groups stemming from migration.
\end{abstract}

Keywords: old minorities, new minorities, diversity, integration, minority protection, accommodation 


\section{Introduction}

In the recent decades, most European countries have experienced a marked increase in the number of migrants residing on their territories. Partly for political and humanitarian reasons, partly as a result of differing economic situations as well as the freedom of movement entailed by the growing economic integration in Europe, an increasing number of people with distinctive identities in terms of language, culture, or religion have settled, with varying degrees of permanence, in countries other than their countries of origin (Eurostat, IOM, UNHCR).

Although economic actors and decision-makers generally recognize the useful contribution to the labour force and the positive impact on the demographic structure of a steadily ageing population, the presence of large immigrant and refugee communities poses manifold challenges in the sphere of integration, cultural differences, protection of individual and group rights, preservation of social cohesion and unity. As a result, most European states have been searching for models and policies to accommodate diversity claims and integrate new minority groups stemming from international mobility flows.

Considering that today the principal cause of the emergence of minorities in the world is migration, the present paper contends that it is possible to address major issues concerning diversity management by bridging two fields of research: minorities and migration. Studying the interaction and complementarities between 'old' and 'new' minority groups is a rather new task because so far these topics have been studied in isolation from each other. It is also an important task for future research in Europe, where many states have established systems of 'old' minority rights but have not yet developed sound policies for the diversity management of new minority groups originating from migration.

The present paper seeks to analyse whether it is possible to reconcile the claims of historical minorities and of new groups originating from migration and whether policies that accommodate traditional minorities and migrants are allies in the pursuit of a pluralist and tolerant society. The paper will ultimately address the question whether it is possible to develop a defensible model for diversity management that reconciles unity and diversity and that overcomes, at the same time, the traditional 'old-new' minority dichotomy.

\section{Old and New Minorities: Still a Valid Dichotomy?}

The terms historical, traditional, and autochthonous minorities - the 'old minorities' - refer to communities whose members have a distinct language, culture, or religion as compared to the rest of the population and who have become minorities through the redrawing of international borders, having seen 
the sovereignty of their territories shift from one country to another. These are ethnic groups that have not achieved statehood on their own for various reasons and that have now become part of a larger country (or several countries): they are the so-called 'old minorities' or 'sub-state nations'. In many but not all cases, their co-ethnics may be numerically or politically dominant in another state, which they therefore regard as their 'external national homeland', or kin-state. ${ }^{1}$

New minority groups stemming from migration - the 'new minorities' - refer to groups formed by individuals and families who have left their original homelands to emigrate to other countries: these are the so-called 'new minorities'. In most cases, their reasons are economic, although political reasons play an increasingly important role as well. New minorities thus consist of migrants, refugees, and their descendants who are living in a country other than that of their origin, on a basis that is more than merely transitional.

It must be acknowledged that the term 'new minorities' is subject to difficulties and criticism as it seems to imply that migrants and individuals with a background of migration are in a 'minority' position, such that their status is 'minoritized'. On the contrary, the term underlines the diversity accompanying these individuals and groups, which requires protection and promotion if desired. The use of the term is intended to refer to 'distinct' groups, and it by no means implies a weakening of their status. On the contrary, it aims to offer additional legal tools with which to respond to their specific needs for protection. ${ }^{2}$ Moreover, the term 'new minorities' is broader than the term 'migrants' as it encompasses not only the first generation of migrants but also their descendants, extending to include second and third generations of individuals with a background of migration, many of whom have been born in the country of immigration and who cannot objectively or subjectively be subsumed under the category of 'migrants'. Moreover, as stated previously, the term 'new minorities' emphasizes

1 It has to be noted that there is a subtle continuum between minority groups and indigenous peoples. Without entering into details in this controversial issue, it has to be admitted that the debate about the difference between indigenous peoples and minorities is indeed complex. It is not easy to distinguish between a group that calls itself an 'indigenous people' and a group or minority that recognizes itself as being native to a given territory and that invokes that characteristic in order to obtain its rights.

2 On this point, see the comment made by the Advisory Committee of the FCNM on BiH, in which it noted that 'Bosniacs and Croats in the Republika Srpska as well as Serbs in the Federation could also be given the possibility - in case they so wish - to rely on the protection provided by the Framework Convention. Taking into account the organizational autonomy enjoyed and the wide powers exercised by the Cantons in the Federation, the same possibility could also be given to the Croats and the Bosniacs living in the Cantons where they constitute a numerical minority. The Advisory Committee wishes to make clear that this possibility would by no means imply a weakening of their status as constituent peoples as provided for by the Constitution, but merely aim at offering an additional tool to respond to a specific need for protection' (ACFC 2004a, paragraph 28). 
the diversity of the individuals concerned as well as their related individual and collective rights, ${ }^{3}$ whereas the term 'migrants' does not. ${ }^{4}$

It is important to note that some countries use regularly the term 'minorities' to refer to immigrants living on their territories. For instance, in the United Kingdom, the term 'ethnic minorities' is used in preference to 'migrants'. This terminological preference reflects a policy of regarding legally resident migrants (particularly those who were born in the country concerned) as a permanently established part of the population. The term 'migrants' is avoided because it not only implies that they moved to the country but also because, as said earlier, it is simply incorrect to describe persons born in the country of migrant parents as 'migrants' (Murray 1997: 219). Use of the term 'ethnic minority' in such contexts, however, in no way necessarily implies the existence of any legal minority status. Its significance is rather administrative in that it may qualify them or their associations for various grants and make them potential beneficiaries of equal opportunity policies, but it does not necessarily entail other rights included in specific instruments on minority rights.

A crucial matter in discussing issues related to the diversity management of minorities - 'old' and 'new' alike - is that claims of minorities are often perceived as a challenge and antagonistic to the traditional model of homogeneous 'nation-states' because both groups seek to increase opportunities within this model to express their identities and diversities at individual and group level. Moreover, historical minorities and migrants are often perceived as foreigners to the community of shared loyalty towards the state and shared rights guaranteed by that state. Members of historical minorities and migrants are seen as loyal to their kin-state or to the state whose citizens they are and to whose sovereignty they belong to as long as they are not absorbed into the national body through assimilation or naturalization.

3 One vexing yet unresolved question concerns whether minority rights have a collective or an individual dimension. From the collective perspective, the minority group itself is the beneficiary of the protection to be afforded. In the individual perspective, the beneficiaries are the individual members of the group. A third position draws upon the formula of individual rights as 'collectively exercised', representing a middle road between the rights of individuals and full collective rights. In the current debate on the individual or collective dimension of minority rights, a pragmatic position holds that, because human experience has endowed human beings with both individual and social dimensions, there is no dichotomy between the individual or collective dimension and that there is therefore no need to choose. As stated by Marko, 'These two forms of rights not only can but even must be used cumulatively when organising equality on the basis of difference' (Marko 1997: 87).

4 Most international instruments for the protection of migrants (e.g. the UN 1990 International Convention on the Protection of the Rights of All Migrants Workers and Members of Their Families, the CoE 1977 Convention on the Legal Status of Migrant Workers, or the EU 2004 Directive on the status of third-country nationals who are long-term residents) contain only vague references to the protection and promotion of the identities of migrants, and some even contain potentially conflicting 'integration' requirements, whilst the notion of group rights is completely absent. 
Historically, new minorities stemming from migration have reacted very differently to majority, dominant societies than historical minorities (Walzer 1995). ${ }^{5}$ Unlike historical minorities whose cultural traditions may pre-date the establishment of the state whose members now find themselves citizens, generally, few migrant groups object to the requirement that they must learn the official language of the host state as a condition of citizenship or that their children must learn the official language in school. Migrants usually accept that their life chances and those of their children depend largely on the participation in mainstream institutions operating in the majority language (Kymlicka 2001).

With regard to new minorities but also to a certain extent to traditional minorities, especially in case of mixed marriages, the problems of integration of the second and third generations can be quite acute. Children of second and third generations are in fact subjected to the decisions taken by their parents, and their living between two cultures and languages can be perceived either as an enriching experience or, often, as an excessive burden. This is due to the fact that often the second and third generations of migrants' descendants have less cultural distance from the host society than their parents, but they have not reached a satisfactory degree of integration from a socio-economic viewpoint.

While it is acknowledged that there are exceptions, it can be said that the primary demands insisted on by new minorities are thus mainly directed towards improving their integration in the host communities. New minorities generally seek to reform main public institutions in the host countries in order to provide greater recognition of their identities and greater accommodation of their practices so as to facilitate their participation in these institutions. They may want schools to provide more information about the immigrant experience, workplaces to accommodate their religious holidays or traditional dress, government agencies to provide health care and welfare benefits in a way that are culturally sensitive, and so on (Kymlicka 2001).

5 According to Walzer, immigrants are considered to have made a choice to leave their own original culture and know that the success of their decision will depend on integrating into the mainstream of their new society. In these cases, ethnic diversity arises from the voluntary decisions of individuals or families to uproot themselves and join another society. On the contrary - Walzer argues -, old minorities are settled on their historic homelands. These groups find themselves in a minority position not because they have uprooted themselves from their homeland but because their homeland has been incorporated within the boundaries of a larger state. This incorporation is usually involuntary, resulting from conquest, colonization, or the ceding of territory from one imperial power to another. Under these circumstances, it is argued that minorities are rarely satisfied with non-discrimination-individual rights model and eventual integration. What they desire, Walzer says, is 'national liberation', that is some form of collective self-government, in order to ensure the continued development of their distinct culture (Walzer 1995: 139-154). This differentiation is, however, questionable mainly because it is debatable whether migrants have really made a voluntary 'choice' to migrate. This applies not only to refugees or those fleeing from wars or natural disasters but also to the so-called 'labour migrants' who escape from economic distress. 
On the contrary, historical minorities generally resist assimilation more strenuously, despite economic incentives and political pressures to do so, and prefer instead to seek official recognition for the separate and autonomous use of their language and enjoyment of their culture. ${ }^{6}$ Hence, the claims of historical minorities do not only concern the equal treatment of their members and the preservation and development of their identity within the dominant society but also those aiming at guaranteeing the effective participation in public life for their members through measures that range from territorial or non-territorial forms of autonomy to secession. ${ }^{7}$

The differences between minority and majority groups, old and new alike, may be profound or may be difficult to discern. However, what distinguishes all minority groups is that they manifest, albeit implicitly, a desire to maintain a collective identity which differs from a dominant culture. Culture in this context is not synonymous with particular practices, customs, or manners of dressing. It is a sense of communal self-identity that pervades almost every aspect of life, including work and economic activity. It is the 'traditions of everyday life' (Wheatley 2003: 508).

In the current discussion on minority issues, it is debated whether the scope of application of international treaties pertaining to minorities that are usually applied to historical, old minorities can be extended to new minority groups stemming from migration (Kymlicka 2007, Hofmann 2006, Hofmann 2004, Medda-Windischer 2009, Medda-Windsicher 2011). The positions in this regard are extremely diversified: among the states, some have adopted rather narrow views firmly opposing the extension of minority provisions to new minorities (Germany, Estonia) (FCNM 1995a; FCNM 1997), others have instead pragmatically applied some provisions to new groups (United Kingdom, Finland) (ACFC 2001a, paragraph 14; ACFC 2004b), and some others have not yet taken an official position. Most international bodies dealing with minorities have adopted an open approach, especially the Advisory Committee on the Framework Convention (ACFC 2001b, p. 34; ACFC 2002a, p. 40; ACFC 2002b, paragraph 18), the European Commission for Democracy Through Law (Venice Commission 2007), the UN Human Rights Committee (HRC 1994, paragraph 5.1-5.2), the UN Working Group on Minorities (Eide 2000), and the OSCE High Commissioner on

6 See, among others, Article 5(2) of the CoE Framework Convention for the Protection of National Minorities, which protects persons belonging to national minorities from assimilation against their will. It does not prohibit voluntary assimilation, and it does not preclude member states from taking measures in pursuance of their general integration policy.

7 In general terms, territorial autonomy involves the granting of separate powers of internal administration, to whatever degree, to entities possessing some ethnic or cultural distinctiveness without those areas being detached from the state. The creation of new political units which enable members of historical minorities to exercise self-governing powers over public institutions are variously referred to as multinational federations, quasi-federal autonomy, or extensive self-government regimes. 
National Minorities, which has recently extended its mandate to new minority groups stemming from migration (OSCE 2004, OSCE 2006, Ekéus 2006).

This broad state's margin of discretion as to the beneficiaries of minority protection depends largely on the fact that, on the whole, drafters of international instruments have been so far unsuccessful in efforts to define the term 'minorities'. Indeed, in international law, there is no generally recognized legally binding definition of the term 'minority', not to mention ethnic, religious, or linguistic minorities, despite several attempts in the past decades to elaborate such concepts. A significant amount of energy and time has been spent over the past five decades by various international organizations in the quest for a generally acceptable definition of the term minority, mainly for codification purposes, yet no conclusive results can be reported. In the case of the UN Declaration on the Rights of Persons Belonging to National or Ethnic Religious and Linguistic Minorities as well as the CoE Framework Convention for the Protection of National Minorities, drafters expressly avoided a definition of the term 'minorities', leaving this to the courts, parliaments, governments, or other bodies involved in the interpretation of these instruments.

However, an approach that leaves the question of minority definition open to the state's margin of appreciation is not fully satisfactory because it can lead to inconsistent implementation to minority groups that find themselves in analogous situations of the same provisions by different states in breach of the principle of non-discrimination. ${ }^{8}$

Along the line of the most quoted definition of minorities - the Capotorti's definition (Capotorti 1977) $)^{9}$, on the basis of a combination of objective and subjective elements - i.e. ethnic, cultural, religious, or linguistic characteristics, residence or legal abode, numerical minority, non-dominant position, and a sense of solidarity or will to survive -, a general definition of minorities can be formulated as follows: a minority is any group of persons, (i) resident within a sovereign state on a temporary or permanent basis, (ii) smaller in number than the rest of the population of that state or of a region of that state, (iii) whose members share common characteristics of an ethnic, cultural, religious, or linguistic nature that distinguish them from the rest of the population, and (iv) manifest, even only implicitly, the desire to be treated as a distinct group. ${ }^{10}$

8 Any reliance in an international instrument on the notion of 'minorities', as in Article II-81 of the Charter of Fundamental Rights of the European Union, should be based on a common legally binding definition of minorities and should not be subject to diverse interpretations in different Member States. Moreover, insofar as the notion of rights of minorities is relied upon in the future EU accession processes with respect to Turkey - as it should, according to the criteria defined by the Copenhagen European Council of June 1993 -, the understanding of the concept of minority should be clarified.

9 In the Capotorti definition, only nationals/citizens of the state concerned are included (see Capotorti 1977, paragraph 568).

10 The requirement to manifest the desire to be treated as a 'distinct group' includes in the definition 'constitutive peoples' as those existing in $\mathrm{BiH}$. 
In this definition, the element of citizenship, which is usually required by states in order to limit the personal scope of application of most international instruments on minorities, is replaced by the element of residence or legal abode (Bauböck 1994). ${ }^{11}$ This general definition would be the basis for advocating the extension of the scope of application of international instruments pertaining to minorities, in particular the CoE Framework Convention for the Protection of National Minorities as to include new minority groups originating from migration. This extension would reverse the fact that, as seen above, most international instruments on migrants' rights contain only vague and weak references to the protection of migrants' identity and diversity. But the protection of the identity of minorities, and in particular of new minorities, is one of the bases of a veritable process of integration in which minority groups can develop a genuine sense of loyalty and common belonging with the rest of the population without being threatened of being forcibly assimilated in the mainstream society, which as a result can endanger resistance and alienation.

A general common definition of minorities is based on the conviction that in spite of their differences old and new minorities share some common characteristics and thus voice similar claims, namely the right to existence, the right to equal treatment and non-discrimination, the right to identity and diversity, and the right to the effective participation in cultural, social, and economic life and in public affairs (Eide 1993). ${ }^{12}$ Alongside common claims, the rationale behind the protection for old and new minorities has likewise a common basis, namely maintaining and promoting peace and security, protecting human rights and cultural diversity as well as democratic participation and democratic pluralism (Åkermark 2007: 8).

While there are evident differences between old and new minority groups, these relate only to certain rights in the international catalogue. This is not a

11 This approach follows the concept of civic citizenship endorsed in most recent EU instruments from the Charter of Fundamental Rights of the Union to the Long-Term Residents Directive for Third Country Nationals (TCNs) aiming at putting member state nationals and long-term third-country residents on a similar legal footing. The civic citizenship would be acquired by third-country nationals after five years' of residence in an EU country and would entail rights comparable to those of EU citizens, including the right to free movement and establishment throughout the European Union. The concept of civic citizenship is based on the idea of taking the residence requirement as a criterion to bring migrant and other minorities' rights and duties, as well as access to goods, services, and means of civic participation, progressively into line with those of the nationals of the country in which they live, under conditions of equal opportunities and treatment. In this perspective, integration of migrants and members of minorities would be measured in terms of citizenship rights rather than nominal citizenship status (see Bauböck 1994, paragraph 3.1).

12 This is also the article-by-article approach favoured by the Advisory Committee of the Framework Convention and by Eide, Asbjørn, former Chairman of the former UN Working Groups on Minority. He summarized this point by saying: 'The scope of rights is contextual' (see Eide 1993, paragraph 27). 
matter of interpretation; it is clearly expressed in the international instruments. For instance, the most relevant legal instrument on minority protection, the Framework Convention for the Protection of National Minorities, contains only three articles that condition their entitlements on 'traditional' ties, which, according to the Explanatory Report of the Framework Convention, are not necessarily only those of historical minorities. In this regard, the Explanatory Report states, rather ambiguously, that the term 'inhabited ... traditionally' referred to by Art. 10(2), Art. 11(3), and Art. 14(2) of the FCNM - 'does not refer to historical minorities but only to those still living in the same geographical area' (FCNM 1995b, paragraph 66). These provisions pertain to the use of the minority language in public administration and on public signs and also in relation to education in the mother tongue; all other entitlements relate to all individuals who may be in the position of a minority, thus old and new minorities alike, groups officially recognized as national minorities and those not recognized, individuals with or without the citizenship of the country in which they live.

In particular, the right to identity and diversity represents in many ways the essence of the case for minorities within the corpus of human rights - the claim to distinctiveness and the contribution of a culture on its own terms to the cultural heritage of mankind. The identity to be protected and promoted may be national, ethnic, cultural, religious or linguistic, or taken all together. The concept of identity is a broad and important concept for individuals and communities since it concerns their belonging, their way of thinking, feeling, and acting. Consequently, respect for and protection of identity can be considered as constitutive elements of respect for human dignity that is clearly a common attribute to the so-called 'old' and 'new' minorities alike. ${ }^{13}$

As often is the case within the international normative system of human rights, there are close links between the right to identity and other rights contained in the catalogue of international human rights: the right to education, language rights, freedom of religion, freedom of expression and information, and freedom of assembly and association.

The claims of minorities to preserve their identity in terms of language, religion, and cultural practices can be a matter of high priority for some minority groups but of lower importance for others until they have received proper equal protection of their basic human rights. Protection of identity entails, at the very least, the right to use one's own language in non-official contexts, the freedom of opinion and its expression, including the right to publish in any language

13 On the protection and promotion of identity, see Art. 5 of the FCNM and Art. 1 of the UN Declaration on the Rights of Persons Belonging to National or Ethnic, Religious or Linguistic Minorities. The right to be different is proclaimed by Art. 1(2) of the 1978 UNESCO Declaration on Race and Racial Prejudice. See also the Convention on the Protection and Promotion of the Diversity of Cultural Expressions adopted by the UNESCO General Conference on 20 October 2005, which preserves and promotes 'creative' diversity. 
without restrictions, and the freedom to practice one's religion in any way not infringing the rights of others. States shall not only abstain from policies which have the purpose or effect of assimilating the minorities into the dominant culture (negative action), but they shall also protect them against activities by third parties, which have assimilatory effect (positive action).

Crucial in regard to the right to identity are, for instance, language policies. Denying minorities the possibility to learn their own language or the transmission of the knowledge of their own culture, history, and tradition would be a violation of the obligation to protect their identity. ${ }^{14}$ At the same time, although people belonging to minorities are not under a legal obligation to integrate, they are aware that if they want to participate in the wider national society, they have to acquire, for instance, a proper knowledge of the official language. In this respect, international norms set out two general parameters: on the one hand, preserving identity and, on the other hand, integrating into the overall national society while keeping one's identity. ${ }^{15}$

Obviously, when reference is made to universal human rights or some basic norms of minority protection, there is no need to distinguish between persons belonging to ethnic, religious, or linguistic groups made up of recent immigrants or those living in a given territory from time 'immemorial'. Other claims, such as the claim to use a minority language in relations with the authorities or the claim to street names in the minority language, are more specific and need to be differentiated.

In these contexts, the form of settlement in which the minority group lives is also relevant: in the case of historical minorities living compactly, forms of territorial autonomy can be the best solution to be negotiated, whereas where minorities live dispersed among the majority, not forming a majority in any substantial area, other forms of institutionalization of these rights are required, which may well include non-territorial, functional variants of autonomy. Obviously, effective participation in public life includes not only participation in political life and how an adequate representation should be devised but also participation in cultural, social, and economic life.

14 See Article 14 FCNM, Article 29 of the 1989 Convention on the Rights of the Child, Article 13 of the 1966 International Covenant on Economic, Social and Cultural Rights.

15 See Art. 6 FCNM. According to the Explanatory Report of the FCNM on this article: 'In order to strengthen social cohesion, the aim of this paragraph is, inter alia, to promote tolerance and intercultural dialogue, by eliminating barriers between persons belonging to ethnic, cultural, linguistic and religious groups through the encouragement of intercultural organisations and movements which seek to promote mutual respect and understanding and to integrate these persons into society whilst preserving their identity' (paragraph 49) [emphasis added]. See also Art. 12 FCNM that according to the Explanatory Report: '...seeks to promote knowledge of the culture, history, language and religion of both national minorities and the majority population in an intercultural perspective'. 


\section{A Common but Differentiated System of Protection}

The conviction that minority groups, regardless of being old or new minorities, have some basic common claims, can be subsumed under a common definition, and the rationale of their protection is fundamentally the same does not mean that all minority groups have all the same rights and legitimate claims: some have only minimum rights, while others have or should be granted more substantial rights; some can legitimately put forward certain claims - not enforceable rights - that have to be negotiated with the majority, while others not. For instance, the members of any minority have the right to use their own language, in private and public, with anyone who is prepared to communicate with them in that language; but not all minorities or not all of their members have the legitimate claim to receive state-funded education in their own language or to use their own language in communication with public officials.

In this context, the difference is not (only) based on the fact that a given group belongs to the 'old' or 'new' minority category: other factors are relevant and apply indistinctively to old and new minorities alike such as socio-economic, political, and historical factors, legacy of past colonization, or forms of discrimination but also the fact that members of a minority live compactly together in a part of the state territory or are dispersed or live in scattered clusters or the fact that members of a community having distinctive characteristics have long been established on the territory, while others have only recently arrived. Minority groups, old and new minority groups, are not a sort of indistinctive monoliths but are composed of groups very different from each other. The catalogue of minority rights has been so far implemented to historical minorities without an abstract differentiation among various minority groups but by taking into account other more pragmatic factors, such as those mentioned above. The same approach should be applied when extending minority protection to new minority groups stemming from migration.

In order to develop a common but differentiated system of protection, it is crucial to differentiate between justifiable rights and legitimate claims. The former - justifiable, or enforceable rights - are rights expressly provided in legal norms or that can be deducted from legally binding judgments such as those of the Strasbourg Court. The latter - legitimate claims - refers to claims that acquire strength from contextual, specific factors. The classification of a claim as 'legitimate' is based on factors that cannot be reduced to the old/new minority dichotomy, but it is based on contextual factors such as long presence on a territory, type of settlement (compact, scattered, or dispersed), past forms of discrimination, colonial legacy, contribution to the history or economy of the wider national society, and so on.

The table below identifies and differentiates a set of rights and legitimate claims that can be demanded by either old minorities or new minority groups 
stemming from migration or both groups. This scheme is largely based on the jurisprudence of the European Court of Human Rights (hereinafter as 'Strasbourg Court' or 'ECtHR') but also on the views and opinions of other international monitoring bodies such as the UN Human Rights Committee and the Advisory Committee of the Framework Convention. ${ }^{16}$

Table 1. Old/new minorities: a common but differentiated system of minority protection

\begin{tabular}{|c|c|c|c|c|}
\hline & \multicolumn{2}{|c|}{ OLD MINORITIES } & \multicolumn{2}{|c|}{ NEW MINORITIES } \\
\hline Typology of Claim & Justifiable right* & $\begin{array}{c}\text { Legitimate } \\
\text { claim** }\end{array}$ & Justifiable right* & $\begin{array}{c}\text { Legitimate } \\
\text { claim** }\end{array}$ \\
\hline \multicolumn{5}{|l|}{ Language } \\
\hline $\begin{array}{l}\text { Use of minority } \\
\text { language in } \\
\text { elected bodies }\end{array}$ & no & $\begin{array}{l}\text { yes } \\
\text { (but knowledge } \\
\text { of the official } \\
\text { language may be } \\
\text { required) }\end{array}$ & no & $\begin{array}{l}\text { no } \\
\text { (not reasonable/ } \\
\text { feasible) }\end{array}$ \\
\hline $\begin{array}{l}\text { Use of minority } \\
\text { language } \\
\text { with public } \\
\text { administration }\end{array}$ & no & yes & no & $\begin{array}{l}\text { no } \\
\text { (not reasonable/ } \\
\text { feasible) }\end{array}$ \\
\hline $\begin{array}{l}\text { Use of minority } \\
\text { language } \\
\text { in judicial } \\
\text { proceedings }\end{array}$ & $\begin{array}{l}\text { yes } \\
\text { (but no if there } \\
\text { is evidence } \\
\text { of sufficient } \\
\text { knowledge } \\
\text { of the official } \\
\text { language) (ECtHR, } \\
\text { Kamasinski v } \\
\text { Austria) }\end{array}$ & $\begin{array}{l}\text { yes } \\
\text { (even in case of } \\
\text { knowledge of the } \\
\text { official language) }\end{array}$ & $\begin{array}{l}\text { no } \\
\text { (but yes if there } \\
\text { is evidence of } \\
\text { insufficient } \\
\text { knowledge of the } \\
\text { official language) }\end{array}$ & $\begin{array}{l}\text { no } \\
\text { (not reasonable/ } \\
\text { feasible) }\end{array}$ \\
\hline \multicolumn{5}{|l|}{ Education } \\
\hline $\begin{array}{l}\text { Publicly funded } \\
\text { education in } \\
\text { minority language/ } \\
\text { religion }\end{array}$ & $\begin{array}{l}\text { no } \\
\text { (unless provided } \\
\text { for other groups) }\end{array}$ & $\begin{array}{l}\text { yes } \\
\text { (states may } \\
\text { legitimately } \\
\text { require respect for } \\
\text { certain principles/ } \\
\text { values in the } \\
\text { curricula) }\end{array}$ & $\begin{array}{l}\text { no } \\
\text { (unless provided } \\
\text { for other groups) }\end{array}$ & $\begin{array}{l}\text { yes } \\
\text { (states may } \\
\text { legitimately } \\
\text { require respect for } \\
\text { certain principles/ } \\
\text { values in the } \\
\text { curricula) }\end{array}$ \\
\hline
\end{tabular}

16 The Strasbourg system is particularly appropriate for the purpose of the present study as the judgments of the European Court of Human Rights are legally binding upon state parties and thus their impact is more effective than the views of the UN Human Rights Committee or the opinions of the Advisory Committee of the Framework Convention. Besides, the geographical limitation of this instrument and the higher degree of homogeneity among its Member States in comparison to the UN instruments simplify the process of searching for a consensus around the issues brought under its scrutiny. For the full text of the judgments of the Strasbourg Court, see the official webpage of the Court at: <http://www.echr.coe.int/ECHR/EN/Header/Case-Law/ HUDOC/HUDOC+database/>. For a detailed analysis of the ECHR judgments relevant to this present study, see Medda-Windischer 2009. 


\begin{tabular}{|c|c|c|c|c|}
\hline & \multicolumn{2}{|c|}{ OLD MINORITIES } & \multicolumn{2}{|c|}{ NEW MINORITIES } \\
\hline Typology of Claim & Justifiable right* & $\begin{array}{c}\text { Legitimate } \\
\text { claim** }\end{array}$ & Justifiable right* & $\begin{array}{c}\text { Legitimate } \\
\text { claim** }\end{array}$ \\
\hline $\begin{array}{l}\text { Use of minority } \\
\text { language in public } \\
\text { education }\end{array}$ & $\begin{array}{l}\text { no } \\
\text { (unless initially } \\
\text { provided and then } \\
\text { abrogated) (ECtHR, } \\
\text { Cyprus v Turkey) }\end{array}$ & $\begin{array}{l}\text { yes } \\
\text { (empirical } \\
\text { evidence in } \\
\text { different forms/ } \\
\text { contexts: South } \\
\text { Tyrol, Catalonia, } \\
\text { Québec, etc.). } \\
\text { More emphasis on } \\
\text { the knowledge of } \\
\text { minority language }\end{array}$ & no & $\begin{array}{l}\text { yes } \\
\text { (empirical } \\
\text { evidence mainly } \\
\text { as extracurricular } \\
\text { classes) } \\
\text { More emphasis } \\
\text { on the knowledge } \\
\text { of the official } \\
\text { language }\end{array}$ \\
\hline $\begin{array}{l}\text { Political } \\
\text { Participation } \\
\end{array}$ & & & & \\
\hline $\begin{array}{l}\text { Electoral rights } \\
\text { (passive/active } \\
\text { rights) }\end{array}$ & $\begin{array}{l}\text { yes } \\
\text { (on the basis } \\
\text { of citizenship, } \\
\text { otherwise no) }\end{array}$ & & $\begin{array}{l}\text { no } \\
\text { (in case of } \\
\text { individuals } \\
\text { without } \\
\text { citizenship of } \\
\text { the country of } \\
\text { residence) }\end{array}$ & $\begin{array}{l}\text { yes } \\
\text { (at least at local } \\
\text { level) }\end{array}$ \\
\hline $\begin{array}{l}\text { Participation in } \\
\text { decision-making } \\
\text { (e.g. reserved } \\
\text { seats/quota/ } \\
\text { advisory bodies) }\end{array}$ & $\begin{array}{l}\text { no } \\
\text { (but no } \\
\text { interference from } \\
\text { the Strasbourg } \\
\text { Court if forms of } \\
\text { participation - } \\
\text { exemptions from } \\
\text { threshold/quota - } \\
\text { are recognized) } \\
\text { (ECtHR, Lindsay } v \\
\text { the U.K.) }\end{array}$ & $\begin{array}{l}\text { yes } \\
\text { (empirical } \\
\text { evidence/ } \\
\text { precedents at local } \\
\text { and national level) }\end{array}$ & $\begin{array}{l}\text { no } \\
\text { (but no } \\
\text { interference from } \\
\text { the Strasbourg } \\
\text { Court if forms of } \\
\text { participation - } \\
\text { exemptions from } \\
\text { threshold/quota - } \\
\text { are recognized) } \\
\text { (ECtHR, Lindsay } V \\
\text { the U.K.) }\end{array}$ & $\begin{array}{l}\text { yes } \\
\text { (at least at local } \\
\text { level) }\end{array}$ \\
\hline $\begin{array}{l}\text { Autonomy } \\
\text { (Local/territorial/ } \\
\text { regional) }\end{array}$ & no & $\begin{array}{l}\text { yes } \\
\text { (empirical } \\
\text { evidence; South } \\
\text { Tyrol, Catalonia, } \\
\text { etc.) }\end{array}$ & no & $\begin{array}{l}\text { no } \\
\text { (no empirical } \\
\text { evidence as well } \\
\text { as decisions of } \\
\text { the Strasbourg } \\
\text { Court in this } \\
\text { sense) (ECtHR, } \\
\text { Kalifatstaat } v \\
\text { Germany) }\end{array}$ \\
\hline
\end{tabular}

* Justifiable rights can be enforced in court (national and international tribunals); they are based on norms directly enforceable, i.e. European Convention in Human Rights, or are inferred from ECHR case-law.

** Legitimate claims have to be negotiated with the majority and depend on contextual factors such as the type of settlement (scattered/concentrated), long or recent presence, legacy with past colonization or forms of discrimination, specific contribution to the history of a country, and so on. 
To clarify the difference between justifiable rights and legitimate claims, examples can be taken from the so-called 'symbolic ethnocultural disputes', which, in contrast to 'claims of assistance rights', are disputes regarding aspects pertaining to the identity of a minority group that do not directly affect the ability of a group to enjoy or live according to its culture. These aspects range from how the state names groups or places through what historical figures are honoured with public buildings named after them or statues to special constitutional recognition of founding peoples or official languages. These disputes are about claims to recognition: recognition as a (or 'the') founding people of the polity or recognition as a group which has made important contributions to the state in which they live.

In this context, the demand to have a minority language be made one of a state's 'official' languages (or the demand to eliminate or prevent the category of 'official languages' altogether) is a symbolic one albeit one that might have an important impact on the whole range of assistance language claims. In these cases, groups with long-lasting, traditional ties to a given territory, groups that were settled on a territory before the 'social contract' or the constitutive national agreement was reached among the national groups or groups that have made special contributions to the state where they live or with whom the state has a legacy of past discrimination, colonization, slavery (for instance, Afro-Americans in the US, Jews in Germany, etc.) - all these groups may formulate claims that, although cannot be defined as enforceable rights, acquire 'legitimization' and have more weight in the negotiations with majority groups due to the above considerations.

Moreover, in case of lack of clarity or uncertainty from legal provisions, precedents or contextual factors as to whether a specific demand is an 'enforceable' right or a 'legitimate' claim, a general principle can be inferred from the analysis of relevant human rights and minority legal provisions and the case-law of main human rights bodies, particularly the Strasbourg Court.

The claim to use a minority language in the context of education can serve to illustrate this principle: despite the fact that both groups, old and new minorities, are under the obligation to learn the official language of the majority, in areas inhabited by old minorities, members of the majority can be sometimes obliged to learn the minority language (for instance, in South Tyrol, where the members of the Italian-speaking group living in South Tyrol are under the obligation to learn the minority language, German, at school and must provide evidence of the knowledge of the minority language if they want to obtain a post in the public administration of the Province of South Tyrol), whereas the same obligation cannot be found, at least as Europe is concerned, in areas inhabited even largely by new minorities.

Therefore, if it is true that managing the diversity of minorities is intrinsically asymmetrical due to the fact that members of minorities, both old and new, are under more pressure than members of the majority to 'adapt' to the majority society, 
in terms of language knowledge or recognition of qualifications, for instance, in the case of old minorities, this asymmetry is more acute and demanding on the side of the majority.

\section{Conclusions}

The differences between minority and majority groups, old and new alike, may be profound or may be difficult to discern. However, what distinguishes all minority groups is that they manifest, albeit implicitly, a desire to maintain a collective identity which differs from a dominant culture. Culture in this context is not synonymous with particular practices, customs, or manners of dressing. It is a sense of communal self-identity that pervades almost every aspect of life, including work and economic activity. It is the 'traditions of everyday life' (Wheatley 2003: 508).

Many, especially among governments' representatives, worry that by extending the definition and protection of minority rights to migrants, they will claim the recognition of rights and powers similar to those granted to traditional minorities, thereby threatening unity and diluting the protection intended for old minority groups.

However, if it is true that in Western countries some immigrant groups demand certain group rights, it would be incorrect to interpret immigrant demands for recognition of their identities as the expression of a desire, for instance, for selfgovernment (Kymlicka-Opalski 2001: 32-36). Migrants are generally aware that if they want to access the opportunities made available by the host countries, then they must do so within the economic and political institutions of these countries. For example, it is still the case that immigrants must learn the official language to gain citizenship or to get government employment or to gain professional accreditation. Active civic participation and effective integration amongst immigrants are essential to the economic prospects of most migrants and indeed to their more general ability to participate in the social and political life of the host country (EC 2005).

Obviously, this leaves open the possibility that some leaders of ethnic groups hope that integration policies will provide a channel for obtaining separatist policy. But, as Kymlicka observes, this is a vain hope, which massively underestimates the sort of support needed to create and sustain a separate societal culture: '[S] ustaining a certain culture is not a matter of having yearly ethnic festivals or having a few classes taught in one's mother-tongue as a child. It is a matter of creating and sustaining a set of public institutions through the use of instruments that are similar to those used by the majority in their programme of nation-building, i.e. standardised public education, official languages, including 
language requirements, government employment, etc.' (Kymlicka 1997: 52-56). So far, there is no evidence from any of the major Western immigration countries that immigrants are seeking, and succeeding, to adopt a pro-sovereignty political agenda (Kymlicka 1997). Indeed, when attempts have been made, these were rejected by national and international courts. ${ }^{17}$

Clearly, it must be recognized that any decision to bring minorities of immigrant origin within the scope of application of international and/or national instruments pertaining to minorities is bound to be political. But if a country is serious about wanting to integrate immigrants, then that country should not oppose the extension of the scope of application of minority provisions to new minorities. As discussed earlier, this would not entail the extension of the full range of minority protection to all minority groups indistinctively; moreover, it might be seen as a very appropriate political gesture, a way of underlining the importance of integration policy and of sending out a powerful message that populations of immigrant origin are now clearly seen to be an integral though distinctive part of the nation.

\section{References}

ACFC (Advisory Committee of the Framework Convention for the Protection of National Minorities). 2001a. Opinion on the United Kingdom, 30 November, ACFC/INF/OP/I(2002)006.

2001b. Opinion on Austria, 16 May, ACFC/INF/OP/I/009.

2002a. Opinion on Germany, 1 March, ACFC/INF/OP/I/008.

2002b. Opinion on Ukraine, 1 March, ACFC/INF/OP/I/010.2004b, Second Report submitted by Finland, 10 December, ACFC/SR/II(2004)012 (Art. 3). 2004a. Opinion on BiH, 27 May, ACFC/INF/OP/I(2005)003.

ÅKERMARK, Sia Spiliopoulou. 2007. Shifts in the Multiple Justifications of Minority Protection. In: BLOED, Arie-HOFMANN, Rainier-MARKO, JosephMAYALL, James-PACKER, John -WELLER, Marc (eds), European Yearbook on Minority Issues 7(8).

BAUBÖCK, Rainer. 1994. The Integration of Immigrants. Report of the $7^{\text {th }}$ Meeting of the Joint Group of Specialists on Migration, Demography and Employment, Council of Europe, Strasbourg, 15-17 March 1994, CDMG(94) 25.

CAPOTORTI, Francesco. 1977. Study on the Rights of Persons Belonging to Ethnic, Religious and Linguistic Minorities, UN Doc. E/CN.4/Sub.2/384/Rev.1.

17 See the case decided by the European Court of Human Rights, Kalifatstaat v Germany (ECtHR 2006), concerning the ban of an association whose aim was the restoration in Germany of the caliphate and the creation of an Islamic State founded on sharia law. 
EIDE, Asbjørn. 1993. Protection of Minorities. Report submitted to the UN SubCommission on Prevention of Discrimination and Protection of Minorities, Forty-fifth session, 10 August 1993, UN Doc. E/CN.4/Sub.2/1993/34.

2000. Commentary to the UN Declaration on the Rights of Persons Belonging to National or Ethnic, Religious and Linguistic Minorities. Working paper submitted to the UN Working Group on Minorities, Sixth session, 22-26 May 2000, UN Doc., E/CN.4/Sub.2/AC.5/2000/WP.1.

EKÉUS, Rolf. 2006. Statement to the OSCE Parliamentary Assembly. Fifth Annual Winter Meeting, Vienna, 23 February 2006, HCNM.GAL/3/06.

EUROPEAN COMMISSION FOR DEMOCRACY THROUGH LAW (Venice Commission). 2007. Report on Non-Citizens and Minority Rights, CDLAD(2007)001, 18 January 2007.

EUROPEAN COMMISSION. 2005. A Common Agenda for Integration. Framework for the Integration of Third-Country Nationals in the European Union, 1 September, COM(2005) 389.

EUROSTAT. May 2015. Migration and Migrant Population Statistics. At: <http://ec.europa.eu/eurostat/statistics-explained/index.php/Migration_and_ migrant_population_statistics $>$.

ECtHR. 1989. Kamasinski v. Austria. Judgment of 19 December, Series A, No. 168. 2001. Cyprus v. Turkey, Appl. No. 25781/94, judgment of 10 May.

2006. Kalifatstaat v. Germany. Appl. No 13828/4, decision on the admissibility of 11 December.

EU. 2004. Directive Concerning the Status of Third-Country Nationals Who Are Long-Term Residents. OJC 109, 23 January.

FCNM (Framework Convention for the Protection of National Minorities). 1995a. List of Declarations, Declaration by Germany. Dated 11 May 1995 and renewed on 10 September 1997. http://conventions.coe.int.

1995b. Explanatory Report of the FCNM. http://conventions.coe.int.

1997. List of Declarations. Declaration by Estonia dated 6 January 1997. http:// conventions.coe.int.

HOFMANN, Rainer. 2006. The Impact of International Norms on the Protection of National Minorities in Europe: The Added Value and Essential Role of the Framework Convention for the Protection of National Minorities (Council of Europe Document DH-MIN(2006)18).

2004. The Framework Convention at the End of the First Cycle of Monitoring. In: Council of Europe (ed.), Filling the Frame. Five Years of Monitoring the Framework Convention for the Protection of National Minorities (Council of Europe Publishing, Strasbourg).

HRC. 1994. General Comment No 23. The Rights of Minorities (Art. 27). CCPR/C/21/Rev.1/Add.5, 8 April. 
IOM. 2015. World Migration Report 2015. Geneva.

KYMLICKA, Will. 1997. States, Nations and Cultures. Spinoza Lectures, University of Amsterdam, Van Gorcum, Assen.

2001. Politics in the Vernacular, Nationalism, Multiculturalism, and Citizenship. Oxford University Press, Oxford.

2007. Multicultural Odysseys. Navigating the New International Politics of Diversity. Oxford University Press, Oxford-New York.

Kymlicka, Will-OPALSKI, Magda (eds). 2001. Can Liberal Pluralism be Exported? Western Political Theory and Ethnic Relations in Eastern Europe. Oxford University Press, Oxford.

MARKO, Joseph. 1997. Equality and Difference: Political and Legal Aspects of Ethnic Group Relations. In: Franz Matscher (ed.), Vienna International Encounter on Some Current Issues Regarding the Situation of National Minorities. N. P. Engel Verlag, Kehl, Strasbourg, Arlington.

MEDDA-WINDISCHER, Roberta. 2009. Old and New Minorities. Reconciling Diversity and Cohesion. Nomos Publisher, Baden-Baden.

2010. Changing Paradigms in the Traditional Dichotomy of Old and New Minorities. In: Henrard, Kristin (ed.), Double Standards Pertaining to Minority Protection. Martinus Nijhoff Publishers, Leiden.

MURRAY, John. 1997. Should Immigrants or Roma and Sinti be Regarded as Minorities? In: Matscher, Franz (ed.), Vienna International Encounter on Some Current Issues regarding the Situation of National Minorities. N. P. Engel Verlag, Kehl, Strasbourg, Arlington.

OSCE High Commissioner on National Minorities. 2006. Policies on Integration and Diversity in Some OSCE Participating States. Exploratory study prepared by the Migration Policy Group, HCNM.GAL/6/06, 3 July.

UNHCR. 2015. Global Appeal 2015 Update. At: http://www.unhcr.org/ga15/ index.xml.

WALZER, Michael. 1995. Pluralism: a Political Perspective. In: Kymlicka, Will (ed.), The Rights of Minority Cultures. Oxford University Press, Oxford.

WHEATLEY, Steven. 2003. Deliberative Democracy and Minorities. European Journal of International Law 14(3): 507-527. 